\title{
With God on Our Side
}


A volume in the series

The Culture and Politics of Health Care Work

edited by Suzanne Gordon and Sioban Nelson

A list of titles in this series is available at www.cornellpress.cornell.edu. 


\title{
With God on Our Side
}

The Struggle for Workers' Rights in a Catholic Hospital

\author{
Adam D. Reich
}

ILR PREsS

AN IMPRINT OF

Cornell University Press

ITHACA AND LONDON 


\section{Copyright $\mathbb{A} 2012$ by Cornell University}

All rights reserved. Except for brief quotations in a review, this book, or parts thereof, must not be reproduced in any form without permission in writing from the publisher. For information, addess Cornell University Press, Sage House, 512 East State Streer, Ithaca, New York 14850.

First published 2012 by Cornell University Press

Printed in the United States of America

Library of Congress Cataloging-in-Publication Data

Reich, Adam D. (Adam Dalton), 1981 -

With God on our side: the struggle for Workers' Rights

in a Catholic hospital/Adam D. Reich.

p. $\mathrm{cm}$. - (The culture and politics of bealth care work)

Includes bibliographical references and index.

ISBN 978-0-8014-5066-2 (cloth : alk. paper)

1. Santa Rosa Memorial Hospital-Employees-Labor unions-

Organizing. 2. Catholic hospitals-_Employecs-m-Labor unions-

Organizing-California-Santa Rosa. 3. Labor movement-

California-Sanca Rosa. 4. Labor-Religious aspects-Catholic

Church. 1. Title. II. Series: Culture and politics of health care work. RA975.C37R445 2012

$$
362.11088-\mathrm{dc} 23 \quad 2011038541
$$

Cornell Universicy Press strives to use environmentally responsible suppliers and materials to the fullest extent possible in the publishing of its books. Such materials include vegetable-based, low-VOC $v$ and acid-free papers that are recycled, totally chlorine-free, or party composed of nonwood fibers. For further information, visit our website at www. cornellpress.cornell.edu.
Cloth printing
10
8

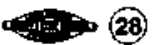


For Teresa 


\section{Contents}

Preface

Acknowledgments

A Note on Names $\quad$ xvii

List of Abbreviations

xix

Introduction: Work's Meaning and Labor's Power

1. The Labor of Love: Vocational Commitments in the Hospital

2. Losing It: The Limits of Economic Interests and Political Power

3. A Struggle over New Things: Contesting Catholic Teaching

4. Winning the Heart Way: Organizing and Cultural Struggle 
viii Contents

5. Trouble in the House of Labor: Alternative Visions of New Unionism 126

Conclusion: What Should Unions Do? 145

Notes 153

Bibliography 167

Index 175 


\section{Preface}

I was out of bed by three in the morning and in Fred Ross Jr.'s station wagon a little after four. Fred Ross Jr. is in his sixties, tall and thin with a dimpled chin. His father, Fred Ross Sr., mentored Cesar Chavez in the early days of the United Farm Worker (UFW) movement. Fred Ross Jr. became a labor organizer with the UFW straight out of college and has spent his life working for a better world in a variety of capacities. In 1975 he led the largest UFW action in a decade, a twenty-thousandperson march from San Francisco to Modesto as part of a successful campaign to pass the Agricultural Labor Relations Act. The law, passed by the California Legislature later that year, was the first in the nation to give farm workers collective bargaining rights, such as the right to organize a union and obtain a contract. ${ }^{1}$ In the 1980s, Ross directed a coffee boycott that helped to end U.S. support for the brutal military government in El Salvador. In the $1990 \mathrm{~s}$ he was Congresswoman Nancy Pelosi's chief of staff in California, before joining with other UFW alumni to lead an immigrant rights campaign. And on this cold and foggy morning when I joined 
the United Healthcare Workers West, Service Employees International Union (SEIU-UHW) for the first day of a big strike at California Pacific Medical Center in San Francisco in the early fall of 2005, Ross had been working for SEIU's hospital division for six years.

Fred Ross Jr. and Eileen Purcell, his colleague at the international union, were charged with developing the union's Catholic hospital strategy. They were both Catholics themselves, and together they were a dynamic duo, a community organizer's dream team. In the $1980 \mathrm{~s}$, Purcell had co-founded the Sanctuary movement for Central American refugees and the National Sanctuary Defense Fund, working especially with the people of El Salvador as they sought to rebuild their lives in the midst of the country's civil war. Before Ross recruited her to SEIU, Purcell had been the executive director of the SHARE Foundation, which also supported organizing efforts by the people of El Salvador. In these roles Purcell forged close and lasting relationships with many religious leaders in the United States and abroad.

Ross's history with the UFW, his leadership of the coffee boycott through Neighbor-2-Neighbor, his extensive political experience, and his law degree mean that he has credibility in almost all aspects of the organizing world. He can rile up a crowd of cafeteria workers as easily as he can build a relationship with a priest or convince a senator to sign a letter. Several workers and organizers have also had the experience of meeting Fred Ross Jt., esquire, when they have been harassed or arrested by the police during an action. Ross often serves as in-street lawyer. Purcell, meanwhile, is able to straddle the worlds of organized labor, international politics, and religion with grace and aplomb-and she is the only organizer l've ever met who has expressed her commitment to worker justice in a published psalm. $^{2}$

As we drove across an empty San Francisco Bay Bridge into the city, Ross regaled me with stories of his days with the UFW. Cesar Chavez had told him to organize farm workers in Oregon, but Ross was hesitant. He had heard that Latinos in Oregon were insular, hostile even to Latinos from California, not to mention a gringo. But over time Ross was able to organize them, proving to himself that anyone can organize anyone else with the right skills. Organizing is a craft, he seemed to be telling me, that transcends an organizer's identity.

We pulled up to the hospital in San Francisco still well before dawn, and on this morning the only skills I put to use were my legs. A bus filled 
with replacement workers circled the hospital, and I tried to prove my chops by taking off after it. What I could do individually to stop a busload of people I wasn't sure. Fortunately, at each entrance where the bus stopped, a crowd of organizers and striking workers shouted, "Scabs, go home!" As a stocky redheaded man on staff of the union pounded on the door of the bus and forcibly prevented anyone from stepping off, the scene brought to mind the heyday of organized labor in the 1930s. And when the bus ultimately was forced to leave, I felt a surge of adrenaline, like this was union power at its essence.

Later that week, as the strike got into full swing, I came back to the hospital and-on the recommendation of a union staff person-pretended to be an expectant father concerned for the safety of my pregnant wife. In our fabricated story, my wife was scheduled to deliver at the hospital the following month. I was instructed to complain about the strike and to try to gather intelligence about what effect it was having on the floor. I complained my way to the nurse director of the obstetrics department before she asked me the name of my wife's obstetrician. I balked, then stammered that we didn't yet have one. The nurse called my bluff. She ordered me not to move and turned quickly away, while I sprinted down the hospital stairs and past a line of beefy security guards. I kept running away from the picket line until I was safely in my car and headed back to my apartment in Berkeley.

Three years later, almost to the day, I actually became a father. On a brisk October evening my wife Teresa gave birth to our daughter Ella at the Berkeley affiliate of the same hospital chain I had helped strike those years before. After a relatively smooth labor and delivery, and two dreamlike days in a beautiful private room overlooking San Francisco Bay, we were about to go home when Ella spiked a fever of 101 . The doctors were worried about a possible infection, and we were told that Ella would have to spend the next three days in the Neonatal Intensive Care Unit (NICU), where she would be hooked up to an IV, given large amounts of antibiotics, and monitored closely around the clock.

The NICU is a glistening shrine to modern medical technology. Premature babies of less than two pounds, who could never have made it fifty years ago, are incubated, respirated, and ushered into healthy and normal lives. But since most of the infants in the NICU are there long term, and many are seriously ill, the place feels sad and somewhat intimidating. 
Nurses do their rounds accompanied by the blips and beeps of monitors, and as a whole don't seem to have much time for parents- who themselves are often compelled to return to something like regular life before their babies are healthy enough to return home, and so appear on the unit only sporadically.

But our case was different. If the tests came back okay, Ella had to be in the unit for only seventy-rwo hours. So Teresa and I spent those hours clinging to Ella as if she were a life preserver in a fierce sea, as we fought off the urge for sleep and the practical (if somewhat cursory) advice of nurses who thought we were being just a little too Berkeley.

Needless to say, Teresa and I nearly lost our minds. It was only thanks to a veteran nurse named Mildred that we stayed on this side of the brink. Mildred had been working at the hospital for almost three decades, and although she had already retired she still took the odd shift. With gentle humor she told us about her own kids, now grown, and warned us that our worries were just beginning - that we should thank our lucky stars Ella was far from being a teenager! She reassured us that Ella would be out of the hospital in no time, and made us feel taken care of amid the flurry and worry of the unit. When Ella's tests came back clear, we wept with gratitude for Mildred's small kindnesses, and she told us that these sorts of experiences were what kept her coming back to the hospital year after year.

These two stories illustrate for me the paradox of work in the hospital. In some ways the hospital is the modern factory, and labor organizing in the hospital is similar to organizing at any other large industrial workplace. In other ways, as Ella's birth brought home to me, the work that goes on in the hospital is loaded with emotion and meaning, giving struggle in the hospital a special character. This book explores in detail the tension between worker power and workers' emotional relationship to their work. For unions to be successful in the healthcare industry and beyond, they must combine an attention to power and control with an appreciation of the cultural context of work-and must link workers' political-economic interests with broader considerations of the public good. 


\section{ACKNOWLEDGMENTS}

This book tells the story of a group of worker leaders, union organizers, and religious allies who overcame countless obstacles to help workers win a union election at Santa Rosa Memorial Hospital, a Catholic hospital in the small city of Santa Rosa, California, about an hour north of San Francisco. These leaders' humor, wisdom, and deep commitment to social justice represent for me what is best about the modern U.S. labor movement. Without their courage and their persistence, there would be no story to tell. I am especially grateful that many of these leaders have been willing to participate in this book. Among them, most of whom I have promised confidentiality, I would like especially to recognize Fred Ross Jr. and Eileen Purcell, who served as my mentors and coaches over the course of my involvement in the campaign. I also owe tremendous debts to Glenn Goldstein and Peter Tappeiner, two organizers on the campaign and ongoing sources of inspiration. Jim Araby, a political organizer on the campaign and a close friend, has read several versions of this project and offered valuable feedback throughout. His breadth and depth of knowledge about 
the labor movement and about modern American politics has helped me immensely as I have tried to connect the lessons of Santa Rosa with the challenges facing the labor movement more generally. He has also been a steady source of moral support in the more difficult days of the writing process.

During my work on the campaign I came to know many religious and community leaders who supported workers in their unionization struggle and deserve special recognition. Monsignor John Brenkle, Father Angelito Peries, Father Ramon Pons, Reverend Blythe Sawyer, Reverend Chris Bell, JoAnn Consiglieri, and Stephen Harper are only some of the many leaders in Sonoma County whose ongoing work gives me hope that meaningful social change is possible.

The publication of a book, it turns out, is a kind of organizing project in itself. Throughout the process, Michael Burawoy has consistently offered a critical eye and supportive ear. He has read and edited countless drafts of the manuscript, but as importantly has encouraged me to pursue a life that balances scholarship with practice, a commitment out of which this book has emerged. Along the way, several other scholars have helped shepherd this project to publication, among them Kim Voss, Ruth Milkman, and Steve Early. Years of conversation with Marshall Ganz about the art and craft of organizing have also helped to inform this project.

At Cornell University Press, Fran Benson, Suzanne Gordon, and Sioban Nelson have been an especially remarkable group of editors with whom to work. Suzanne even came to Berkeley and helped me reshape my introduction in person, with both of us huddled over my laptop in a busy coffee shop. Thanks to Susan Specter and John Raymond for their attention to matters both large and small. The book is much stronger as a result of their editing. Thanks also to an anonymous reviewer solicited by the press who gave quite thorough and thoughtful feedback.

The roots of this project go back even further. My father, Robert Reich, has advocated on behalf of working people since before I was born. He is a role model as an engaged intellectual, not to mention a role model as a father. He was also an enthusiastic participant in the St. Joseph Health System campaign. My mother, Clare Dalton, is even more of a radical-first as a legal scholar and advocate for victims of intimate partner violence, and more recently as an acupuncturist. Her journey continues to inspire me to follow my own conscience, wherever it may lead. Thanks to both 
of them for changing my diapers, for feeding me, and for giving me the right values.

Finally, I would like to thank Teresa Sharpe, my partner, to whom I have dedicated this book. Teresa's own work on the labor movement demonstrated to me how one might balance one's social justice commitments with careful analysis and critique. The first time we met for lunch, over burritos on Berkeley's campus, she shared with me her experiences working for a union while attending graduate school, and encouraged me to do the same. And as our friendship blossomed into marriage and into parenthood, she and I have continued to wrestle with broader questions about worker power and the cultural significance of work-that is, when we're not wrestling with our toddler, Ella. 


\section{A Note on Names}

Social scientists face complicated ethical questions about the degree of anonymity they provide the subjects of their research. For many historians, time has given the events they describe a distance that allows for specificity. Sociologists writing about events closer at hand often occlude the people and places about which they write, creating a different kind of distance between readers and the experiences about which they are reading.

Neither of these solutions felt available to me. The events described in this book are still "raw" to many of the people who experienced them, as one respondent put it. Were I to wait for time to scab over the wounds, I might be waiting a very long time indeed. Yet the specifics of the campaign felt important to the lessons I was able to draw from it. Moreover, I wanted to recognize the successes of workers at Santa Rosa Memorial Hospital and those who worked alongside them.

In order to balance my commitment to specificity with my ethical obligations as a researcher, I have compromised. The people in the text identified by their full names are either interviewees who agreed to be 
identified, or people who were publicly identified in media accounts of the Santa Rosa Memorial Hospital campaign. Those identified by first names only are participants who appear regularly in the story but whose names I have changed in order to protect their anonymity. Those participants in the study who appear only sporadically I have identified by position alone. 


\section{AbBreviations}

AFL-CIO

AFSCME

CHA

CHW

CNA

HERE

NLRA

NLRB

NUHW

SEIU

SEIU-UHW

SJHS
American Federation of Labor and Congress of Industrial Organizations

American Federation of State, County and Municipal Employees

Catholic Health Association of the United States

Catholic Healthcare West

California Nurses Association

Hotel Employees and Restaurant Employees International Union

National Labor Relations Act

National Labor Relations Board

National Union of Healthcare Employees

Service Employees International Union

Service Employees International Union, United Healthcare Workers West

St. Joseph Health System 
SRMH Santa Rosa Memorial Hospital

UAW United Auto Workers

UFW United Farm Workers

UNITE Union of Needletrades, Industrial and Textile Employees

USCCB United States Conference of Catholic Bishops 


\section{With God on Our Side}




\section{INTRODUCTION}

\section{Work's Meaning and Labor's Power}

Santa Rosa Memorial Hospital (SRMH) is nestled in a residential neighborhood a few blocks away from downtown Santa Rosa, an exurban community about an hour north of San Francisco. Even with the prominent blue " $\mathrm{H}$ " hospital signs leading the way, the hospital can be difficult to find for an out-of-towner. A statue of St. Joseph, the earthly father of Jesus, welcomes visitors at the hospital's main entrance, and an old convent, long ago converted into administrative offices, sits adjacent to the facility, a buffer between the hospital and the surrounding community.

Since its founding in 1950, the hospital has been owned by the Sisters of St. Joseph of Orange, a group of nuns who preside over thirteen hospitals in California, New Mexico, and Texas that together make up the not-forprofit St. Joseph Health System (SJHS). Although these Sisters were once actively involved in nursing and administration at Memorial Hospital, their numbers have become too small and too elderly to maintain an active presence there. Yet they still actively govern the health system as a whole 
and still work to infuse each of their facilities with the values they see as central to hospital care.'

The Sisters of St. Joseph of Orange are widely regarded as one of the most progressive orders of nuns in the state, if not the country. Not only were they among the first sisters in the United States to abandon the habit but they actively supported Cesar Chavez and the United Farm Workers throughout the 1960s and 1970s. Several spent time in a Fresno jail with grape strikers in the summer of 1973 . Much to the dismay of these same Sisters, workers at Santa Rosa Memorial Hospital spent more than six years trying to organize a union.

In this book I follow workers' union organizing efforts at Santa Rosa Memorial Hospital between 2004 and 2010. In 2004 and 2005, workers and union leaders attempted to organize within the standard framework of the federal National Labor Relations Board (NLRB). Yet in the face of a concerted and sophisticated antiunion campaign led by management and supported by the hospital's religious leadership, workers and union leaders were forced to withdraw from this election in the face of imminent defeat. The campaign then became more open-ended as the union sought what it termed a "fair election agreement," a set of ground rules and accountability mechanisms that would limit the hospital's antiunion practices. In this effort workers and union leaders organized in the political and religious communities in new ways. Between 2007 and 2008, the union built a community coalition that sought to link the Memorial campaign with the county's broader healthcare crisis. Although the coalition was unsuccessful in its narrower political goals, it was an important part of the union's broader project. Between 2005 and 2009, the union built a powerful religious and political coalition to highlight the contradictions between the values the hospital asserted and its antiunion practices, a project that $d i d$ win important concessions from the hospital corporation in the fall of 2008 . At the very moment of greatest hope, however, the union was thrown into disarray by an internecine labor dispute. When workers finally voted on unionization in December 2010, they did so with few resources and in oppasition to the Service Employees International Union (SEIU), the organization that had helped to initiate the campaign.

Throughout this process workers faced intimidation and harassment from their supervisors, from hospital administrators, and ultimately from the members and leadership of an opposition union. As important, workers 
had to reconcile their desire for more power and voice in their workplace with their vocational commitments to their patients. The obstacles these workers faced, and their ultimate success, make the organizing drive at Santa Rosa Memorial Hospital a crucible within which to examine the challenges and possibilities facing labor unions in service industries across the country.

\section{The Hospital, the Union, and the Twenty-First-Century Workplace}

Today's healthcare sector is one of the largest industries in the United States, employing 14.3 million people, approximately 35 percent of whom work in hospitals. ${ }^{2}$ The hospital has replaced the factory as the main source of employment in many communities. In ciries such as Rochester, Minnesota, and Cleveland, Ohio, well-known centers of medical practice and innovation overshadow the manufacturing industries the hospitals were first constructed to serve. Catholic hospitals are a major player in this industry. In 2009 there were fifty-nine Catholic health systems that together provided almost 15 percent of all hospital care in the United States. $^{3}$

Hospital work has also, in some ways, come to resemble work in the large unionized workplaces of the mid-twentieth century. The fiefdoms of midcentury hospital work have given way to integrated hierarchical organizations that have made even doctors feel less like professionals and more like wage earners. Medical specialization and fragmentation have diminished the importance of the physician-patient relationship by introducing new technologies and new delivery systems that divide treatment into its component parts. ${ }^{4}$ Unlike manufacturing industries, which have moved production offshore in the face of high labor costs, hospitals cannot as easily transfer operations to places where labor is cheaper, nor can they as easily replace labor power with technology. The workforce is fairly centralized and fairly integrated. And as financial pressures increase in the industry, many workers are being squeezed by being asked to work more hours and take on more responsibilities without commensurate increases in pay.

Finally, far from ushering in a free market of relatively autonomous and competitive buyers and sellers, the corporate transformation of the 
U.S. healthcare system has been accompanied by large-scale processes of organizing by the market's constituent parts. ${ }^{5}$ Hospitals have merged in order to negotiate better rates with insurers and physicians, physicians have organized groups in order to negotiate better rates with hospitals and insurance companies, and all three groups have sometimes merged (into health maintenance organizations or preferred provider organizations) in order to negotiate with employers and individual patients. All of these constituencies have used principles of combination to increase their economic leverage with the others.

In these ways the hospital seems a natural site for labor organizing, representing a glimmer of hope in the face of labor's forty-year decline across the private sector. ${ }^{6}$ In other ways, however, the hospital is strikingly different from those workplaces in which the labor movement was born. Since workers in not-for-profit hospitals were first excluded from the protections of the National Labor Relations Act as part of the Taft-Hartley Act of 1947, hospital work has been distinguished legally from other sorts of labor. Not only were hospitals primarily oriented around noneconomic values, it was argued, and so inappropriate targets for unionization, but they were also dealing with matters of life and death, making the threat of work disruption dangerous and immoral. ${ }^{7}$ Even after the protections of the NLRA again were extended to hospital workers in 1974, the law has sought to balance the rights of hospital workers against the rights of the public to uninter rupted hospital care.

If hospital work was the anomaly at midcentury, in 2010 it is representative of the interactive care work so prevalent in today's U.S. economy. The future for American labor seems likely to hinge on its success in industries like health care: industries that orient themselves at least in part toward public goods; industries in which workers' values and emotional lives are closely entangled with their jobs. Even public sector employees such as teachers and social service workers, recently regarded as the last bastion of U.S. unionism, ${ }^{8}$ have found their political and bureaucratic sources of power coming under increasing attack, and must identify new sources of power and legitimacy. The lessons that can be learned from an analysis of hospital organizing have implications far beyond the hospital's walls.

These lessons have implications outside the labor movement as well. Healthcare workers, teachers, social service workers, and other servicesector employees are often those in closest contact with the patients, 
students, and clients they serve. A revitalized labor movement can and must be closely linked to the protection and revitalization of patient care, student learning, and the public good. Union membership is one of the few mechanisms that allow workers to advocate on behalf of the constituencies they serve without fear of reprisal. ${ }^{9}$

Most broadly, this book explores the relationship between vocational values and worker power in the contemporary hospital and beyond. More specifically, it addresses three questions. First, how do hospital workers understand the noneconomic dimensions of their work, and how do these noneconomic values relate to their participation in labor unions? Second, in a.context in which confrontational politics is understood by multiple constituencies as anathema to organizational mission, what should be the character of labor struggle? How can workers successfully challenge their disempowerment when this challenge is itself construed as inappropriate? ${ }^{10}$ And finally, how do these two dimensions of labor struggle-workers' noneconomic values and the ideological face of the corporation-complicate existing debates about labor's power both on the shop floor and in the political arena?

Throughout this book, I argue that for unions to remain relevant in the hospital industry and beyond-winning support among workers, winning campaigns against employers, and winning broad-based political powerthey must recognize the cultural dimension of labor struggle, and must be concerned as much with putting forward a vision of the public good as with winning material advantage. The campaign at Santa Rosa Memorial Hospital-and its relationship to broader successes and failures in the labor movement-illustrates the possibilities and perils of this approach to labor struggle.

\section{Case and Methods}

1 focus on Santa Rosa Memorial Hospital because it epitomizes the values-based not-for-profit employer. Although vocational ethics infuse many care contexts, they are perhaps nowhere more prominent than in the Catholic hospital, where these ethics are articulated explicitly in the form of religious values. When I asked the deacon of a local church why it mattered whether or not a hospital was Catholic, he responded: "You ever 
been scared? ... There isn't any time in the world when religion makes more sense than when you have a problem, especially a health problem, or [are] confronting death." A lead organizer in the union told me that these religious values are "often deeply felt by the workers." This is not to say that workers are necessarily religious themselves, but rather that the religious mission of the hospital resonates with their experience of the noneconomic aspects of their work. According to Sioban Nelson, a professor of nursing, workers want "to provide healthcare to all in their facilities with the highest respect and dignity for the patient and their families." People "feel good about those missions." Nelson documents how Catholic nuns established modern nursing "as a hybrid religious and professional practice." This legacy lives on in the way that many workers relate to hospital work, perhaps most acutely in those hospitals founded by Catholic nuns.

It was Fred Ross Jr. who brought me up to Santa Rosa for the first time in the spring of 2006. As a first-year graduate student in sociology at UC Berkeley, I was interested in learning more about the theory and practice of labor organizing, and made a deal with myself to keep one foot in the world of practice. Like any good organizer, Ross wasn't satisfied with just one foot, and he suggested that I become one of the union's religious organizers. So over the next year and a half I worked about fifteen hours a week for the union, building relationships with local religious leaders, introducing them to hospital workers, and asking them to support the campaign in various ways. No matter that I was a nonpracticing Jew whose religious experience was limited to bar and bat mitzvahs and the occasional High Holy Days.

Throughout my involvement with the campaign I took detailed field notes, oftentimes reluctantly, as my world of practice had come temporarily to overshadow my academic ambitions. When I dove back into graduate work more wholeheartedly, between February 2009 and October 2010, I conducted open-ended interviews with worker leaders, union organizers, religious leaders, and hospital administrators and executives.

This book also makes use of a rich body of primary documents produced by both union and management over the course of the campaign. These include strategic memos written by union staff; public memos from the hospital administration to workers; flyers both for and against the union that were distributed to workers at the hospital; public advertisements taken out by both union and administration in local media outlets; media stories 